\title{
Tabularia
}

Sources écrites des mondes normands médiévaux

Actes épiscopaux et abbatiaux en Normandie et dans

le grand Ouest européen | 2011

\section{Delineating the Development of English episcopal chanceries through the Signification of Excommunication}

L'évolution des chancelleries épiscopales anglaises à travers les sentences

d'excommunication

\section{Philippa Hoskin}

\section{OpenEdition}

Journals

\section{Electronic version}

URL: http://journals.openedition.org/tabularia/597

DOI: 10.4000/tabularia.597

ISSN: $1630-7364$

Publisher:

CRAHAM - Centre Michel de Boüard, Presses universitaires de Caen

\section{Electronic reference}

Philippa Hoskin, « Delineating the Development of English episcopal chanceries through the

Signification of Excommunication », Tabularia [Online], Actes épiscopaux et abbatiaux en Normandie et dans le grand Ouest européen, Online since 14 November 2011, connection on 01 May 2019. URL :

http://journals.openedition.org/tabularia/597 ; DOI : 10.4000/tabularia.597 


\title{
Delineating the Development of English episcopal chanceries through the Signification of Excommunication
}

\section{L'évolution des chancelleries épiscopales anglaises à travers les sentences d'excommunication}

\author{
Philippa Hoskin \\ Department of History \\ University of Lincoln \\ phoskin@lincoln.ac.uk
}

\begin{abstract}
:
Significations of excommunication are a neglected source for administrative history, yet their diplomatic provides valuable information. This paper examines significations issued by English bishops from the dioceses of Coventry and Lichfield, Exeter, Lincoln, Salisbury and York where thirteenth-century registers exist, or once existed, considering the relationship between common diplomatic form and early registration. It demonstrates that the episcopal register was not the apotheosis of the English episcopal chancery. The structure of episcopal registers developed in parallel with the use of common form, revealing chanceries still in flux and that those dioceses with the earliest registers were not necessarily the most organised by the start of the fourteenth century.
\end{abstract}

Keywords: church, administration, excommunication, dioceses, chancery, bishops.

Résumé:

Les sentences d'excommunication demeurent une source négligée de l'histoire administrative, bien que leurs formes diplomatiques fournissent des informations intéressantes. Cet article examine les excommunications fulminées par les évêques de cinq diocèses anglais dans lesquels existent ou ont existé des registres $d u X^{X I I I}{ }^{e}$ siècle, en prenant en compte la relation entre les formes diplomatiques communes et l'enregistrement précoce. Cela démontre que le registre épiscopal ne constitue pas l'apogée de la chancellerie épiscopale en Angleterre. La structure des registres épiscopaux, développés parallèlement à l'usage de formes communes, révèle des chancelleries encore en mutation et montre que les diocèses disposant le plus précocement de registres n'étaient pas nécessairement les plus efficaces au début du XIV viècle.

Mots-clés: église, administration, excommunication, diocèses, chancellerie, évêques.

Cheney's seminal history of English episcopal chanceries traced their development up to 1250 and noted that from the end of the twelfth century episcopal documents were being produced by bishops' own chanceries rather than by beneficiaries, and that the standardisation of these acta demonstrated 
'a high standard of expertness in the clerks who drafted and wrote them'1. The story of episcopal administrative development in the remainder of the thirteenth century has been considered in far less detail. In English dioceses of the thirteenth and early fourteenth centuries episcopal registers have drawn the attention of administrative historians who have focussed on their content, form and derivation, and it has been implied that these registers marked high point of episcopal administrative development in each individual diocese, although surprise has been expressed at their late appearance in England if episcopal chanceries existed in the twelfth century ${ }^{2}$. The registers do not, however, mark a clear line in the sand. Early registers are experimental in content, structure and layout, demonstrating that the chancery was continuing to develop its functions and differentiate roles within itself. This paper will consider what the diplomatic form of one class of document, the signification of excommunication, from the thirteenth-century English dioceses of Coventry and Lichfield, Exeter, Lincoln, Salisbury and York, can say about the development of episcopal writing offices and how these suggest that whilst writing offices' achievements were remarkable, even by the late thirteenth century some bishops' chanceries were working in a reactive rather than forward-thinking way.

Tracing the development of particular, chancery-related roles within episcopal households is one way to consider chancery development, but the records which provide the most consistent evidence for a bishop's familia - the witness lists of his episcopal charters - fail in many English dioceses at precisely the critical point, the second half of the thirteenth century, remaining in abundance only in charters relating to the bishops' temporal possessions where chancery members are less common witnesses ${ }^{3}$. Another way forward is through a study of the diplomatic - the standard phrases and structure - of episcopal acta. As demands on the chancery increased in competence certain types of documents would be expected to become increasingly similar in format - in fact all but identical. This is tested here by examining a class of records issued in large numbers, with little need for variation within the documents, looking for evidence of sustained standardisation across more than one episcopate.

Significations of excommunication - requests from the bishop or other ecclesiastical officials for the issuing of the writ de excommunicato capiendo instructing the relevant county's sheriff to arrest individuals who have remained excommunicate in contempt of the Church for forty days or more - are one such class. They began to be issued in England in the 1220s and are particularly common from the 125 os onwards ${ }^{4}$. For the purposes of the present discussion their value is twofold. Firstly they survive in large numbers. Their appearance

1. Cheney, 1950, p. 98.

2. On the late introduction of registers see ChURChill, 1933, p. 4; ChURChill, 1962, p. 12; Jenkins, 1920, p. 41; Cheney, 1950, p. 108-109; Cheney, 1956, p. 65; RAIne, Register Gray, p. viii; Phillimore, Rotuli Welles, p.1; Fowler, p.103; Foster, 1935, p.155-156; Frankforter, 1982, p. 67-89.

3. Keмr, English Episcopal Acta 36, p. cii; Hoskin, English Episcopal Acta 38, p.cvi-cvii.

4. For a detailed discussion of significations, see LoGAN, 1968. 
is linked to the growth of the episcopal, consistory courts of England, also particularly tied to the second half of the thirteenth century, and they were issued regularly. Although ephemeral, as their receipt led to the issuing of a de cursu writ they were often retained by the royal chancery as evidence of request for issue. Over 2,80o of these survive for the thirteenth century in the English National Archive today, and Logan's work has suggested that such files make up at least $75 \%$ of significations issued ${ }^{5}$. Secondly, these documents had good reason to be in common form. They were all making one simple, standard request and the need to issue them in large numbers would have discouraged creative phrasing, whilst at the same time it was necessary for certain phrases and concepts to be included consistently for the documents to be legally valid, so attention still had to be paid to their composition ${ }^{6}$.

Ideally this study would cover all the extant thirteenth-century significations issued following episcopal registration but this is not practical in a piece of this length. Nor will there be space to draw comparisons with the work of other established chanceries such as that of royal government. Rather, this paper will concentrate on significations in five dioceses, Coventry and Lichfield, Exeter, Lincoln, Salisbury and York, in each case from the time of their first appearance up to 1300 and compare them with parallel developments in registration, as far as they are known, in those administrations. York and Lincoln provide the two earliest surviving sets of registers and also had extensive jurisdiction - due to provincial authority, in the case of York, and the sheer geographical extent of the see, in the case of Lincoln - which would make an organised chancery a distinct administrative advantage. They also both had particular identifiable, long-term officials who have been considered influential in the growth and development of their respective chanceries. Does the diplomatic of their significations bear out the thesis that they had a developed administration which can be identified by the existence of registers, or which coincides with the arrival of these well-known officials? This study also considers the diocese of Exeter as representing those dioceses which had registers from the mid-thirteenth century, beginning in 1257. What do their significations add to the picture? Finally, the dioceses of Coventry and Lichfield and of Salisbury are known to have had early registers which are now lost. Their significations will be published within the English Episcopal Acta series late into the thirteenth century - could the existence of registers here be inferred from the diplomatic of these documents?

In considering the significations it is important first to lay down what standard means. Palaeographical studies of thirteenth-century significations from Hereford and London suggest that significations were written by new scribes as part of their training, they could therefore be expected to include errors ${ }^{7}$. Simple transposition of words, the omission of individual words or short phrases where no adjustment is made in the rest of the document to account for the loss, and

5. Ibid., p. 66.

6. Ibid., p. 148 .

7. Barrow, English Episcopal Acta 35, p. xcvi; Hoskin, English Episcopal Acta 38, p.cxv. 
the occasional replacement of single words particularly where an abbreviation in draft could have been misunderstood - for example dominus for deus - can be expected. Any more deliberate or definite change, for example the inclusion of a new phrase within an otherwise previously used standard form, will however, define the document as a new form. There are also two distinct types of common form. In one type the main body of the document - the dispositio - which includes the detail of the request is found in standard form but the protocol and eschatocol - in particular the address, the episcopal title, the salutation and the valediction or farewell clause - differ. In the other the whole document, with all its elements, is standard. Both forms are found in the dioceses considered here, and either can demonstrate standard practice.

The extensive jurisdictions of York and Lincoln are familiar places for beginning a study of episcopal administration, as they represent the earliest surviving English episcopal registers. At York, the archiepiscopal registers start in 1225 within the episcopate of Walter de Grey (1215-1255). Yet for this archiepiscopate and those following, to the end of that of Walter Giffard (1266-1279), significations remain non-standard even within an episcopate. These registers precede even the earliest English significations and none of the 343 surviving thirteenth-century examples for the see of York can be dated earlier than $1245^{8}$. In the early years of a new type of document confusion about its diplomatic could be expected, but it is still striking that over the next twenty years the form did not develop any sort of consistent diplomatic phrasing under the York chancery. Within this period the format of the registers was also in flux. The earliest, under Gray ${ }^{9}$, were in roll form, arranged chronologically although an attempt was made to separate spiritual business from temporal (the latter being reserved to the dorse of the roll), and nothing now survives for the brief episcopates of Sewal de Bovill and Geoffrey Ludham. Giffard's register was in the easiest form for referral, that of the book ${ }^{10}$, but although there was some attempt at classification of material within the register, by geographical area, this was not completely consistent ${ }^{11}$.

Developments in both common form amongst the significations and the organisation of episcopal registers are found under William Wickwane (12791285) and John Romeyn (1286-1296) ${ }^{12}$. Setting aside two individual, very unusual significations $^{13}$, at the start of Wickwane's archiepiscopate two versions of the signification emerge, with the dispositio of the second differentiated from the first only by one clause concerning the keys of the Church. The first main form, which also included a standard valediction and intitulatio and used just two variant

8. For York significations see TNA, C 85/169, C 85/170, C 85/171, C 85/172 C 85/173, C 85/174, C 85/175; C $85 / 153 / 38$.

9. Borthwick Institute for Archives, Archbp Reg. 1, edited RaIne, Reg. Gray.

10. Borthwick Institute for Archives, Archbp Reg. 2, edited Brown, Reg. Giffard.

11. SMith, 1981, p. 234; Frankforter, 1982, p. 87.

12. Borthwick Institute for Archives, Archbp Reg. 3 and Archbp Reg. 4, edited Brown, Register Wickwane and Brown, Register Romeyn.

13. TNA, C 85/173/18 and 90 . 
salutations, appears on 109 occasions $\mathrm{s}^{14}$ of which two were issued sede vacante, in 1285 at the end of Wickwane's episcopate ${ }^{15}$ and nine are in the name of the vicar general, issued whilst the archbishop was absent in the same year ${ }^{16}$. The second is found 32 times $^{17}$, of which again five were issued by the vicar-general in the archbishop's absence of $1285^{18}$. There is no obvious way of differentiating between these two forms in terms of circumstances of issue: the second is not dated from particular manors or within a particular date span within the episcopate - both types appear from 1279 onwards - and is not found in a particular hand or set of hands not associated with the alternative form. At Romeyn's succession the first form becomes that used consistently ${ }^{19}$, now also with a standard inscriptio, but continuing to make use of the same two forms of salutatio. One document from this episcopate has a clause omitted and one a different form of greeting ${ }^{20}$, but the only remarkably different forms are in significations issued in the names of other officials - one by the prior of Durham, one by the archdeacon of Richmond and twenty-three in the name of the archdeacon of the East Riding acting as bishop's official: presumably these men had their own clerks and were not making use of the archbishop's clerks ${ }^{21}$.

The York registers also developed significantly in this period. Smith has noted that Wickwane's register marks an advance in internal organisation with new subdivisions relating to peculiar jurisdictions and sections for administratively important documents such as licences to study at the schools granted to the clergy ${ }^{22}$. Romeyn's register went further: its sectional divisions demonstrate a simplification of the system and became the model for later registers of the diocese, a development which has been attributed to John Nassington, who entered the archiepiscopal household under Romeyn as a scribe and worked as official principal under the next five archbishops ${ }^{23}$. Both registers also clearly had a use beyond the immediate checking of administrative facts. Wickwane's register survives in two copies (albeit not identical) bound in the same volume - suggesting that the chancery was concerned to preserve it for future not just immediate referral - and both Wickwane's register and

14. TNA, C 85/172/53, 56, 57, 59, 60, 62-65; C 85/173/1-4, 6, 7, 9-14, 16, 17, 19, 20, 23, 24, 26, 28-33, 35-39, $41,44,47,49,51,52,54-59,60-61,65-68,71-88$, 92; C 85/174/2-13, 16, 17, 22-24, 26, 28-32, 34-36, $41-44,46,48,49$.

15. TNA, C 85/173/76 and 77 .

16. TNA, C 85/173/65-68, 71-77.

17. TNA, C 85/172/50, 52, 54, 58; C 85/173/5, 8, 15, 21, 22, 25, 27, 34, 40, 42, 43, 45, 48, 50, 53, 62-64, 69, 70; C 85/174/14, 18-21, 40, 45, 47.

18. TNA, C 85/173/62-64, 69, 70 .

19. TNA, C $85 / 174 / 43$ on; C $85 / 175$.

20. TNA, C $85 / 175 / 23$.

21. TNA, C 85/175/44; C 85/175/49; C 85/175/47-69. In 1288, John Nassington as vicar-general makes use of the standard archiepiscopal form when issuing significations in the archbishop's absence (TNA, C 85/174/49, 50, 52-59): he would have had access to the bishop's chancery but probably not a separate chancery of his own.

22. SмIтн, 1981, p. 234.

23. Hamilton Thompson, 1936, p. 249. 
Romeyn's seem to have been used as formularies. The earlier of these two registers (1279-1285) includes notes for drafters of documents beside specific registered documents or groups of documents such as 'here are several arengae suitable for use in indulgences' ${ }^{24}$. Romeyn's register, $1285-1296$, begins with a contemporary index noting particular documents useful for standard forms ${ }^{25}$, and the documents themselves are often adapted to reflect this. The signification included, for example, is taken from a specific example but altered to include two salutations, with a note that either could be used and with interlined plural versions of relevant nouns and verbs to allow for easy adaptation to significations for more than one individual, given in the form:

\begin{abstract}
Serenissimo principi domino suo domino E. Dei gratia regi Angl' illustri domino Hibern' et duci Aquit' Iohannis permissione eiusdem Ebor' etc salutem in eo per quem reges regnant et regna cuncta subsistunt vel sic salutem in eo cui servire perhenniter est regnare. Excellencie vestre regie notum facimus per presentes, quod Stephanus vicarius de Lexinton clericus[ci] et parochianus[ni] noster[ri] per nos auctoritate ordinaria ob ipsius[orum] contumaciam et offensam maioris excomunicationis sententia innodatus[ti] in ea per quadraginta dies et amplius animo indurato pertinaciter perduravit[runt] et adhuc contemptis ecclesiasticis clavibus perseverat[ant] Quocirca regie celsitudini supplicamus quatinus ad insollenciam predicti[orum] rebellis[ium] salubrius reprimendam litteras vestras si placet velitis concedere secundum preoptentam meritoriam et piam consuetudinem regni vestri ut quod minus valet mitis mater ecclesia in hac parte vestre magestatis potentia supleatur. Conservet vos ecclesie et populo suo dominus per tempora diuturna. Dat etc anno gratie etc nostri pontificatus ${ }^{26}$.
\end{abstract}

This is a record of the common form already in use in the diocese: one for which Nassington can not have been responsible: he was not, therefore, the instigator of increased organisation in the chancery although he no doubt encouraged it. These registers may well have continued in use as formularies beyond the particular episcopate in which they were created. They were after all long-term records of reference for the diocese, and passed on to the chancellor or, later, the registrar by the sede vacante jurisdiction at the start of each new episcopate. Certainly the standard form of signification identified here continues to be used in the next archiepiscopate. The introduction of common form in significations at York, then, comes after the introduction of episcopal registers, but arises at the same period as those registers themselves become more standardised in format and are arranged to be used as the formularies necessary for common form. In fact the standardised significations are part of the increased organisation of the York episcopal chancery also evidenced by the registers.

\footnotetext{
24. Brown, Register Wickwane, p.303.

25. For a description see Hamilton Thompson, 1936, p. 249.

26. Borthwick Institute for Archives, Archbp Reg. 4, fo. 69r. Bracketed letters are the alternative plural endings interlined in the manuscript.
} 
At Lincoln the picture is different in terms of the use of common form but again reflects something of the level of organisation seen within the see's registers. From this diocese come the earliest surviving English episcopal rolls beginning under Hugh of Wells, in 1215. It is a commonplace amongst historians that these were influenced by from Hugh's time in the royal chancery and his consequent understanding of the need for record keeping ${ }^{27}$, and they are a remarkable achievement ${ }^{28}$. They are also the work of an extensive chancery in terms of numbers of clerks ${ }^{29}$. As at York, significations began somewhat later than the registers: they start only in the 1250 under Bishop Robert Grosseteste ${ }^{30}$. Across 330 significations issued in the name of the bishop of Lincoln up to 1300, there is no real indication of consistent diplomatic form between episcopates. There are 43 extant significations from Grosseteste's episcopate now identified, and across the period of the episcopate ten are in the form given by Davis in his edition of Grosseteste's register ${ }^{31}$, whilst the remaining documents are in two similar but not identical diplomatic. Henry of Lexington's brief episcopate (1254-1258) again produces similar but not identical forms. Under Richard Gravesend (1258-1279) there is much more variation, however, and within the episcopate of Oliver Sutton whilst 30 significations, from 1288 to 1299 , share a dispositio in the form:

Dominacioni vestre celsitudini patefacimus per presentes quod [name] nostre diocesis propter ipsius contumaciam pariter et offensam est maioris excommunicationis sentencia auctoritate ordinaria innodatus, in qua per quadraginta dies et amplius animo perstitit indurato, claves ecclesie contempnendo. Quocirca excellentie vestre attentius supplicamus quatinus ad maliciam dicte [name] cohercendam secundum consuetudinem regni vestre dignemini extendere dexteram maiestatis ${ }^{32}$.

and an additional 26 across the same date range are in the same form but replacing 'contumaciam pariter et offensam' with 'offensam/contumaciam manifestam'33, other forms are also used. Here the hypothesis that registration could precede high-level organisation of the diocese is taken to extremes. A re-examination of the general state of episcopal record keeping in this see also suggests that registration was not in itself a reliable indicator of chancery organisation. It is true that even the early rolls suggest careful recording of institutions ${ }^{34}$, although

27. Cheney, 1950, p. 107.

28. SмITH, 1972, p. 155-195.

29. On Hugh of Well's chancery see SMITH, 2000, p. xxxii-xxxiv.

30. TNA, C 85/97. TNA, C 85/97/1 declares itself to be dated 1206: but the hand, and the fact that it is issued in the name of $\mathrm{H}$. bishop of Lincoln, demonstrate that this is a scribal error for 1256 and the document was actually issued under Henry of Lexington.

31. TNA, C 85/97/3-5, 7, 11, 17, 20, 24, 26, 70. Printed DAvis, Rotuli Grosseteste..., p. 504.

32. TNA, C $85 / 101 / 2,3,4,5,11,13,14,15,16,17,18,21,22,26,27,29,31,33,34,36,38,42,43,49,50$, $51,52,54,59 ; \mathrm{C} 85 / 100 / 75$.

33. TNA, C 85/101/1, 6, 7, 9-10, 12, 19, 20, 28, 32, 35, 39, 40, 44, 45, 46, 47, 48, 53, 56, 57, 58, 61, 62, 64, 67.

34. On careful use of language in these rolls see Michael Burger, 'Sending, Joining, Writing and Speaking'..., p. 151-182. 
Frankforter has noted that these rolls are not consistent in their choice of what to register and are the work of a still experimenting and unsure chancery ${ }^{35}$, and it is also true that the loss of some rolls, at least from Hugh of Wells' and Robert Grosseteste's episcopates ${ }^{36}$, and probably under other bishops, also means that the structure of the system is now partially lost to us. However, the diocese in the 1280 os is known to have struggled with record keeping: John Schalby, registrar from 1280 on, had to undertake a re-organisation of the episcopal archive in $1284^{37}$. It is also notable that Lincoln retained the roll format for so long. Although convenient for travel - the small Lincoln rolls would have had this advantage over the larger, far more cumbersome rolls kept by Archbishop Gray at York - these did not provide an easy overview of work in the diocese. The roll was a convenient method of recording events but a less convenient form for consultation ${ }^{38}$. As Cheney has noted, it is in fact not clear that a diocese using this format would have thought of the individual rolls as forming part of a single register at all ${ }^{39}$. Schalby's introduction of a book rather than a roll in 1290 may have been the start of a completely new approach to registration and the preservation of episcopal documents in the diocese, although it is notable that he was not responsible for introducing common form in significations and there is no Lincoln formulary, to compare with Romeyn's register at York, dated earlier than the fifteenth century ${ }^{40}$. The registers themselves, setting aside the emphasis upon institutions, remained comparatively confused and disorganised - particularly in terms of the memoranda they chose to include - well into the fourteenth century ${ }^{41}$. Such a slow process of administrative development is not improbable in such an extensive diocese, where developing record keeping and creation may not have been the primary concern of a registry perhaps struggling to manage its vast amounts of business. Hill calculated that the surviving rolls of Bishop Oliver Sutton at Lincoln amounted to 930,000 words and as Forrest has noted, if this is only a small part of the chancery's output, its total business must have been of immense size ${ }^{42}$. Each entry additionally reflected a document already issued as an original document - perhaps more than one - and many acta were never registered at all. A brief calculation suggests that the surviving significations alone include another nearly 25,000 words.

35. FrankForter, 1982, p. 86

36. Phillimore, Rotuli Welles..., p. iii; Davis, Rotuli Grosseteste... contains a number of references to missing rolls including memoranda rolls.

37. HILl, 2004 .

38. The author's forthcoming new edition of the rolls of Robert Grosseteste, bishop of Lincoln, will demonstrate the ways in which the chancery attempted to make the rolls easier to consult and that these were not contemporary with the rolls' production. Consultation was clearly not the main concern at point of creation.

39. Cheney, 1951, p. 108.

40. MAJOR, 1953, p.38.

41. I am grateful to Dr Nicholas Bennett, Lincoln Cathedral Librarian, for this information concerning the contents of later Lincoln episcopal registers.

42. HILl, 1951, p. 44; Forrest, 2011, p.5. 
At Exeter, a comparison between the thirteenth-century significations and registers again suggests experimentation and continuing uncertainty. There are no extant significations in this diocese before the start of registration under Walter Bronescombe (1258-1280), although, as at York, this type of document does appear in the same episcopate as the earliest extant register, first occurring in $1264^{43}$. An examination of the 94 surviving significations from then until the end of the century for this episcopate does not provide one dominant standard document form. During Peter Quinel's episcopate (1280-1291) there was one form of dispositio used frequently ${ }^{44}$, but by no means exclusively. There is some small overlap of forms between episcopates: the dispositio found repeatedly under Peter Quinel also appears under his successor Thomas Bitton ${ }^{45}$, but this is not sustained for more than two years and probably reflects a short term overlap in staff supervising or drafting within the chancery. During the same period the surviving episcopal registers (there is no extant register for Bishop Bitton) also suggest a struggle for organisation. Bronescombe's and Quinel's registers (now bound together) are organised only chronologically with no attempt to divide documents by subject or jurisdictional area: only under Stapledon in the early fourteenth century is there some attempt to develop a further internal arrangement ${ }^{46}$.

In the dioceses considered above there is a suggestion that there was a correlation between the growing internal organisation and structuring of episcopal registers and the use of common form in regularly produced small acta, but not between the use of common form in significations and the introduction of the registers themselves. Would examining the significations for two dioceses where registers have disappeared confirm the hypothesis that standardisation of significations' diplomatic follows registration and perhaps even suggest something new about the start of registration there and how organised the chanceries in both these sees really were by the end of the thirteenth century? The dioceses of Salisbury and of Coventry and Lichfield are both known to have lost registers. Swanson has demonstrated that there is evidence for a register produced during Roger Meuland's episcopate at Coventry and Lichfield, apparently kept as a roll, whilst at Salisbury there is definite evidence for registers from every episcopate from that of Walter de la Wyle (1263-71) on, apart from the brief episcopate of Braunstone (1287-1288), and possibly even earlier: Kemp has made a persuasive case for a register of Richard Poore (1217-1228) ${ }^{47}$. Both sees also demonstrate standard forms of signification.

At Coventry and Lichfield, once significations start to appear in large numbers after 1250, they retain the same form, with only the addition of a phrase concerning sealing, through Roger de Weasenham's episcopate (1245-1256) and for the first twenty-five years of Roger de Meuland's administration (1258-1295), up to 1283 , in the form following:

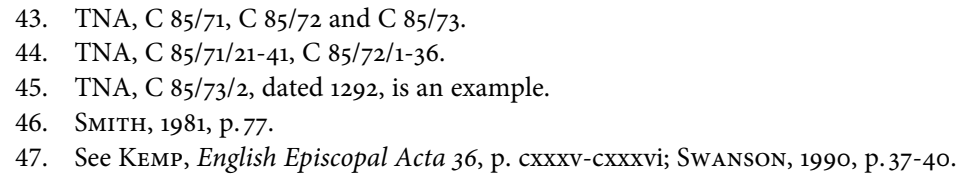


Noverit dominatio vestra quod [name] laicus culpis suis exigentibus excommunicationis sententia meruit innodari, in qua per xl dies et amplius claves ecclesie contempnendo contumaciter perseveravit adhuc incorrigibilis existens. Quapropter serenitati vestre supplicamus attente quatinus predictum excommunicatum ad satisfaciendum Deo et ecclesie secundum consuetudinem regni vestri regia potestate dignemini cohercere ${ }^{48}$.

After this there is a minor but consistent change of one verb - meruit to existit - making a new standard form for the rest of the episcopate, which continues in use after it ${ }^{49}$. Weasenham's documents go further than those of his successor and show almost complete consistency in all their diplomatic elements with an occasional omission of a phrase or change of a single word, whilst under Meuland the protocol and eschatocol of the signification are less standard ${ }^{50}$. At Salisbury early significations are variable, but from 1271 to the end of the century the same standard dispositio is used throughout across the five relevant episcopates, with very occasional lapses into a different form: of 50 surviving significations 44 are in this form ${ }^{51}$.

In Coventry and Lichfield this standardisation, then, precedes the first known survival of a register - although we can not be certain that even earlier registers have not also been lost - whilst at Salisbury standard forms seem to follow on after registration, as though the first episcopal register was once more another step in the development of the chancery rather than its final, crowning achievement. Standardisation at Salisbury also again coincides with other evidence of organised chancery production. The diocese seems, like York, to have had a formulary, dating from the 1270 s with additions from the 1280 ond including a form of signification ${ }^{52}$. The manuscript is identified in the British Library catalogue as belonging to John de Burton, the precentor of Salisbury and sede vacante official, and certainly it does include a number of documents in his name. However, these are largely those issued during his time as sede

48. Denton \& Hoskin, English Episcopal Acta 43, nos. 219-221, 223-224, 276-282; Denton \& Hoskin, English Episcopal Acta 44, nos. 338, 340-354, 356-380, 383-39o, 395-417, 419-420, 423-431, 433-438; TNA, C 85/52/1, 2, 4-14, 17-22, 25-34; C 85/53/1-22, 25-42, 45-49, 51-53; C 85/54/1-38, 40; C 85/55/19.

49. Denton \& Hoskin, English Episcopal Acta 44, nos. 439, 441-446, 448-459, 462-470, 472-482, 484488, 491-494, 496-500, 503, 508-515; TNA, C 85/54/39, 42-51, 53, 54-57; C 85/55/1, 3, 5-18, 20-31, 33-34, 36-37, 40-49.

50. The inscriptio is usually the same as that under Weasenham, addressing the king as Excellentissimo usually followed by domino suo, and early in the episcopate Wesenham's salutation is used twelve times (TNA, C 85/52/7-18) but is then replaced by a variety of forms although the most common is 'successus [semper] ad vota prosperos [iugiter] et felices' (the bracketed words reflecting frequent but not invariable additions) whilst the valedcition varies and is often replaced with a corroborative clause referring to sealing from 1276 on.

51. KемP, English Episcopal Acta 37, nos. 294, 296-299, 305, 307-310, 312-316, 318-333, 336-342, 381, $383-386,415,432$. Interestingly this form is not used in the significations which are issued by the bishops as bishop-elect, before consecration: ibid., nos. 289-293, 382 .

52. Keмp, English Episcopal Acta 37, Appendix 1. This is an edition of the specifically episcopal documents. Given the nature of the edition of the acta as a whole it sensibly omits the sede vacante material and that relating to the election of a bishop. 
vacante official of the spiritualities of the diocese, therefore officially by the diocese and made up of documents only usually issued in the name of members of the episcopate, and are often given only as alternatives to the form to be used by a bishop. The heavy emphasis on episcopal documents, including forms of document for visitation and for election of bishops arising from two different sorts of elections, and the fact that even the rough documents included at the end of the formulary are personal letters issued by bishops, makes it probable, I suggest, that this is actually a formulary belonging to - or at least used by - the episcopal chancery not an individual. Although the formulary provides a whole example of the signification ${ }^{53}$, the repeated standard part of the document found within the acta is the dispositio: other diplomatic elements may or may not follow the formulary example, demonstrating that a formulary was not necessarily consulted for the drafting of the most familiar parts of an actum.

The history of the development of the episcopal chancery in the second half of the thirteenth century has been dominated by the introduction of the episcopal register and these are indeed central to the record-keeping of the diocese particularly in relation to the institutions of clergy. Yet a study of the diplomatic of just one class of documents issued by the bishop's writing-office, the signification of excommunication, provides another way to judge the degree of organisation of an episcopal writing office and that the creation of a register did not indicate that an episcopal chancery had reached its apotheosis. Rather this sample suggests that episcopal chanceries did become increasingly organised in the later thirteenth-century, that this did not coincide with the introduction of episcopal registers, but developed along with the internal structure of the register and that the use of a chancery formulary was an element of this development. In particular the significations demonstrate that the very real - and very human problems of simple document production in a large diocese such as Lincoln could impede administrative advances. Other reasons for new developments and increased organisation - such as the role of innovative and organisationally gifted individuals - are still partially hidden but in both Lincoln and York it is clear that it was not the arrival of a particular individual which marked the introduction of common form, although Schalby certainly, and Nassington possibly, influenced the development of registers in those sees. The lack of early common form also suggests something more, although more tentatively. The assumption of early registration made by historians such as Churchill was largely based on the concept that the episcopal chanceries, managing their increased administrative burdens from the late twelfth century onwards, would of necessity have been highly organised. The examples given here, of growing organisation after the start of registration and in particular in the diocese of Lincoln of an apparent continuing struggle under the burden of day to day administration well into the fourteenth century, suggests that this need not have been the case and in fact that administrative development required time, as well as effective leadership, to develop.

53. Kemp, English Episcopal Acta 37, Appendix 1 no. 12. 


\section{Bibliography}

Barrow, J., "From the Lease to the Certificate: the evolution of Episcopal Acta in England and Wales (c.70o-c.1250)", in Die Diplomatik der Bischosurkunden vor 1250, J.C. HaidACHer and W. KöFler (eds.), Innsbruck, 1995, p. 529-542.

Barrow, J., English Episcopal Acta 35: Hereford 1234-1275, Oxford, Oxford University Press, 2009, CI +275 p.

Brooke, C.N.L., "English Episcopal Acta of the Twelfth and Thirteenth Centuries", in Medieval Ecclesiastical Studies in Honour of Dorothy M. Owen, M. J. FrAnkLIN and C. HARPER-Bill (eds.), Woodbridge, Boydell and Brewer, 1995, p. 41-56.

Brown, W., Register of Walter Giffard, lord archbishop of York, 1266-1279, London, Surtees Society, 1904, XIX + 362 p.

Brown, W., The Register of William Wickwane, lord archbishop of York, 1279-1285, London, Surtees Society, 1907, XXVI + $412 \mathrm{p}$.

Brown, W., The register of John le Romeyn, lord archbishop of York, 1286-1296, part I, London, Surtees Society, 1913, $416 \mathrm{p}$.

Brown, W., The registers of John le Romeyn, lord archbishop of York, 1286-1296, part II, and of Henry of Newark, lord archbishop of York, 1296-1299, London, Surtees Society, 1917, XLIII + $365 \mathrm{p}$.

Burger, Michael, "Sending, joining, writing and speaking in the Diocesan Administration of Thirteenth-century Lincoln”, Mediaeval Studies, 55, 1993, p.151-182.

Cheney, C.R., English Bishops' Chanceries 1100-1250, Manchester, Manchester University Press, 1950, $188 \mathrm{p}$.

Cheney, C.R., From Becket to Langton English Church Government 1170-1213, Manchester, Manchester University Press, 1956, 222 p.

Churchill, I., Canterbury Administration, London, SPCK, 1933, 2 vols, XIII + 615 p., $\mathrm{XV}+367 \mathrm{p}$.

Churchill, I., "The Archbishops' Registers", in Medieval Records of the Archbishops of Canterbury, E.G.W. BILl (ed.), London, Faith Press, 1962, 70 p.

Clanchy, M., From Memory to Written Record, $2^{\text {nd }}$ ed., Oxford, Wiley-Blackwell, 1992, $432 \mathrm{p}$.

Davis, F.N., Rotuli Roberti Grosseteste Episcopi Lincolniensis AD MCCXXXV-MCCLIII, London, Canterbury and York Society, 1914, XII + 557 p.

Denton, J. and Hoskin, P. M., English Episcopal Acta 43: Coventry and Lichfield 12231256, Oxford, Oxford University Press, forthcoming.

Denton, J. and Hoskin, P. M., English Episcopal Acta 44: Coventry and Lichfield 12581295, Oxford, Oxford University Press, forthcoming.

Forrest, I., 'The archive of the official of Stow and the 'machinery' of church government in the late thirteenth century', Historical Research, 84, 2011, p.1-13.

Foster, C.W., 'The Lincoln Episcopal Registers', Reports and Papers of the Architectural and Archaeological Societies of the County of Lincoln and the County of Northampton, 41, 1935, p.155-168.

FOwLER, R.C., Episcopal Registers of England and Wales, London, Dawson, 1918, 32 p.

http://www.unicaen.fr/mrsh/craham/revue/tabularia/print.php?dossier=dossier11\&file=01hoskin.xml 
Frankforter, A.D., "The origin of Episcopal Registration procedures in Medieval England", Manuscripta, 26, 1982, p.67-89.

Hamilton Thompson, A., 'The Registers of the Archbishops of York', Yorkshire Archaeological Journal, 32, 1936, p. 245-263.

Hass, E. de, and Hall, G.D.G. Early Registers of Writs, Selden Society, 1970, 430 p.

HILL, R.M.T., "Bishop Sutton and his archives: a study in the keeping of records in the $13^{\text {th }}$ century", Journal of Ecclesiastical History, 2, 1951, p. 43-53.

Hill, R., "Schalby, John (d. 1333)", Oxford Dictionary of National Biography, Oxford, Oxford University Press, 2004.

Hoskin, P.M., English Episcopal Acta 38: London 1229-128o, Oxford, Oxford University Press, 2011, CXVI + $160 \mathrm{p}$.

JENkins, C., Ecclesiastical Records, London, SPCK, 1920, 84 p.

Kemp, B.R., English Episcopal Acta 36: Salisbury 1229-1262, ed. B.R. Kemp, Oxford, Oxford University Press, 2010, CXXXVI + $261 \mathrm{p}$.

Kemp, B.R., English Episcopal Acta 37: Salisbury 1263-1297, Oxford, Oxford University Press, 2010, XXXII + 380 p.

Logan, F.D., Excommunication and the Secular Arm in Medieval England, Toronto, Pontifical Institute of Medieval Studies, 1968, 259 p.

MAJOR, K., A Handlist of the Records of the Bishop of Lincoln and of the Archdeacons of Lincoln and Stow, Oxford, Oxford University Press, 1953, 122 p.

Phillimore, W.P.W., Rotuli Hugonis de Welles, Episcopi Lincolniensis, 1209-1235 vol. 1, London, Canterbury and York Society, 1903, XXVII + 209 p.

RaIne, J., The Register or Rolls of Walter Gray, Lord Archbishop of York, 1215-1255, London, Surtees Society, 1872, LVIII + 388 p.

SMITH, D.M., 'The rolls of Hugh of Wells, bishop of Lincoln 1209-35', Bulletin of Historical Research, 45, 1972, p.155-195.

Smith, D.M., Guide to Bishops' Registers of England and Wales: a survey from the Middle Ages to the Abolition of the Episcopacy in 1646, London, Royal Historical Society, 1981, $352 \mathrm{p}$.

Smith, D.M., The Acta of Hugh of Wells, bishop of Lincoln 1209-1235, Woodbridge, Lincoln Record Society, 2000, $310 \mathrm{p}$.

Swanson, R.N., 'The rolls of Roger de Meuland, bishop of Coventry and Lichfield (1258-1295), Journal of the Society of Archivists, 11, 1990, p.37-41. 